How to cite this article:

Authors: Emilia Bachtiak-Radka, Sara Dudzińska, Daniel Grochała, Stefan Berczyński

Title of article: „Influence of digital processing of milled surface measurement data on the Sq parameter”

Mechanik, No. 12 (2019)

DOI: https://doi.org/10.17814/mechanik.2019.12.107

\title{
Influence of digital processing of milled surface measurement data on the $S q$ parameter
}

\author{
EMILIA BACHTIAK-RADKA \\ SARA DUDZIŃSKA \\ DANIEL GROCHAŁA \\ STEFAN BERCZYŃSKI *
}

\author{
Mgr inż. Emilia Bachtiak-Radka, ebachtiak@zut.edu.pl, https://orcid.org/0000-0003-3366-0083 - Zachodniopomorski Uniwersytet \\ Technologiczny, Szczecin, Polska \\ Mgr inż. Sara Dudzińska, sara.dudzinska@zut.edu.pl, https://orcid.org/0000-0002-2577-7899 - Zachodniopomorski Uniwersytet Tech- \\ nologiczny, Szczecin, Polska \\ Dr inż. Daniel Grochała, daniel.grochala@zut.edu.pl, https://orcid.org/0000-0003-2553-7739 - Zachodniopomorski Uniwersytet Tech- \\ nologiczny, Szczecin, Polska \\ Prof. dr hab. inż. Stefan Berczyński, stefan.berczynski@zut.edu.pl, https://orcid.org/0000-0002-8403-6355 - Zachodniopomorski Uni- \\ wersytet Technologiczny, Szczecin, Polska
}

Digital processing of recorded measurement data on the milled surface can offer operators many possibilities in the planning metrological procedures processes and give more leeway in the final configuration of the surface geometrical structure condition. Review of the current state of knowledge revolving around surface characteristics, measurement uncertainty and their quality, and primarily reproducibility of measurements not only in the laboratory but also in the industrial environment poses a major challenge. The article presents research works related to the identification of the influence of the measurement data processing method using digital data processing of milled surface on the $S q$ parameter. The analysis of individual stages of measurement data processing showed the direct influence of data filtration methods on the values of the $S q$ parameter.

KEYWORDS: digital data processing, point cloud filtration procedure, geometric structure of the surface, optical measuring systems

\section{Introduction}

Recording measurement data without errors in the shape of surface unevenness allows to opt out of digital processing of these data, so that the values of surface geometrical structure (SGP) parameters are free from random operator influence [1-3]. The methodology for determining the SGP parameter values is simpler when the assumption is made about the ideal (without shape errors) point cloud acquisition. The parameter values without cutting out the threshold values, leveling and filtration - should be reproducible for various measuring systems and allow the classification of measuring devices [9]. Most commercial measuring devices use the phase shift effect [4] or the confocal effect of chromatic light [5-7] in their operation. Standards [4, 5, 7-9] and technical documentation of measuring devices lack detailed information on how to acquire measurement data [9-15]. Only basic rules and recommendations are given [1,3].

In order to identify the impact of the measurement data processing method, experimental studies were carried out. The sample from X160CrMoV121 material was processed by milling and then tested on the AltiSurf A520 measuring machine located at the West Pomeranian University of Technology in Szczecin (ZUT). The measurements were carried out in accordance with the fractional experiment plan developed. It includes a strategy for processing measurement data for subsequent stages: cutting out the threshold values, leveling, removing the shape and filtering. AltiMap PREMIUM version 6.2 was used. The impact of individual data filtration methods on the value of $S q$ parameter, defined as the mean square deviation of surface roughness, was investigated: 


$$
S q=\sqrt{\frac{1}{M \cdot N} \sum_{j=1}^{N} \sum_{i=1}^{M} \theta^{2}\left(x_{i}, y_{j}\right)}
$$

where: $M \cdot N$ - size of the sampling matrix, $\theta\left(x_{i}, y_{j}\right)$ - residual surface (bearing surface).

The paper analyzes the $S q$ parameter, which is determined by the same algorithm as the average effective power of RMS electrical signals. This parameter effectively visualizes variability of the surface deviation from the mean plane. On its basis, it is possible to detect interference and evaluate - by filtering - the "power loss" of the signal due to too strong distortion introduced.

\section{Research material}

The surfaces of $100 \times 100 \times 20 \mathrm{~mm}$ samples made of X160CrMoV121 steel and tempered (with a hardness of $2 \pm 2 \mathrm{HRC}$ ) were tested. This material was chosen because of its use in the design of stamping dies, which were formed by milling on a DMG DMU 60 monoBLOCK machine equipped with a torus head (WNT R1000G.42.6.M16.IK) with six cutting inserts with a diameter of $d_{\mathrm{p}}=10 \mathrm{~mm}$ (RD. X1003 MOT - WTN1205) at an angle of $15^{\circ}$ to the machine axis. Other technological parameters are included in the tab. I.

\section{TABLE I. Milling technological parameters}

\begin{tabular}{|l|c|}
\hline Cutting speed $v_{\mathrm{c}}, \mathrm{m} / \mathrm{min}$ & 110 \\
\hline Depth of cut layer $a_{\mathrm{p}}, \mathrm{mm}$ & 0.5 \\
\hline Feed per revolution $f_{\mathrm{r}}, \mathrm{mm} / \mathrm{rev}$ & 0.6 \\
\hline Milling cross feed $f_{\mathrm{wf}} \mathrm{mm}$ & 0.3 \\
\hline
\end{tabular}

\section{Measurement methodology}

The X160CrMoV121 sample was measured on an AltiSurf A520 machine equipped with a CL2 confocal sensor with a measuring range of $0 \div 400 \mu \mathrm{m}$. The area of the scanned surface was $4 \mathrm{~mm} \times 4 \mathrm{~mm}$, the drilling in the $X$ axis was $6 \mu \mathrm{m}$, sampling in the $Y$ axis $-0.6 \mu \mathrm{m}$ with a scanning speed of $120 \mu \mathrm{m} / \mathrm{s}$, the brightness of the LED was $100 \%$ of the lighting power and the ambient temperature $-21^{\circ} \mathrm{C}$. A fractional trivalent experiment plan was selected. Input factors are described in tab. II.

\section{TABLE II. Description of selected input factors used in the planning of the experiment}

\begin{tabular}{|c|c|}
\hline Factor name & Range \\
\hline $\begin{array}{c}\text { PO } \\
\text { mapped surface }\end{array}$ & - \\
\hline $\begin{array}{c}\text { A } \\
\text { cutting thresholds }\end{array}$ & $\begin{array}{l}\text { 1. } 0.01 \div 99.99 \\
\text { 2. } 0.05 \div 99.95 \\
\text { 3. } 0.10 \div 99.90 \\
\end{array}$ \\
\hline $\begin{array}{c}\mathrm{B} \\
\text { leveling }\end{array}$ & $\begin{array}{l}\text { 1. LS plane (by rotation) } \\
\text { 2. LS plane (by subtraction) } \\
\text { 3. Plane defined by three points ( } 10 \text { points) }\end{array}$ \\
\hline $\begin{array}{c}\text { C } \\
\text { delete shape }\end{array}$ & $\begin{array}{l}\text { 1. 2nd order polynomial } \\
\text { 2. 3rd order polynomial } \\
\text { 3. } 4 \text { th order polynomial }\end{array}$ \\
\hline $\begin{array}{c}\mathrm{D} \\
\text { filtering }\end{array}$ & $\begin{array}{l}\text { 1. Gaussian filter (cutoff } 0.8 \mathrm{~mm} \text { ) } \\
\text { 2. Coarse Gaussian filter (cutoff } 0.8 \mathrm{~mm} \text { ) } \\
\text { 3. Spline filter (cutoff } 0.8 \mathrm{~mm} \text { ) }\end{array}$ \\
\hline
\end{tabular}

Variability of input factors specified in the plan is representative of all SGP testing equipment available on the market and compliant with [5]. According to the experiment plan, 27 experiment systems were analyzed and their results were developed in the AltiMap PREMIUM 6.2 program. 


\section{Processing the results}

The analysis of research results was started by determining the significance of the impact of selected input factors on the value of the $S q$ parameter [7]. To better illustrate the changes that follow the subsequent stages of digital processing of the recorded point cloud, the coefficient of variation of the surface state $K S x$ was determined:

$$
K S x=\frac{S x_{\mathrm{PO}}}{S x_{\mathrm{x}}}
$$

where: $S x_{\mathrm{PO}}$ - value of the SGP parameter of the mapped surface, $S x_{\mathrm{X}}$ - value of the SGP parameter of the surface after performing the specified digital processing operation.

Fig. 1 presents $S q$ values for the mapped surface and for the determined threshold values. Analyzing the individual stages of digital processing of surface data, it can be concluded that after removing the threshold values, the $S q$ value decreased proportionally to the value of the cut out percentage. For case A1 (see tab. II), the value of $S q$ decreased by $0.04 \%$, for case A2 - by $0.18 \%$, and for case A3 - by $0.35 \%$ (fig. 1 ).

Value of $S q$ parameter increased significantly after applying leveling relative to the surface mapped for B3. The plane defined by three points (10 points) increased by $48 \%$ for systems $7-9$ and $25-27$. The leveling method has significant impact on the $S q$ parameter. In other cases, its values decreased by $0.58 \%$ on average (fig. 2).

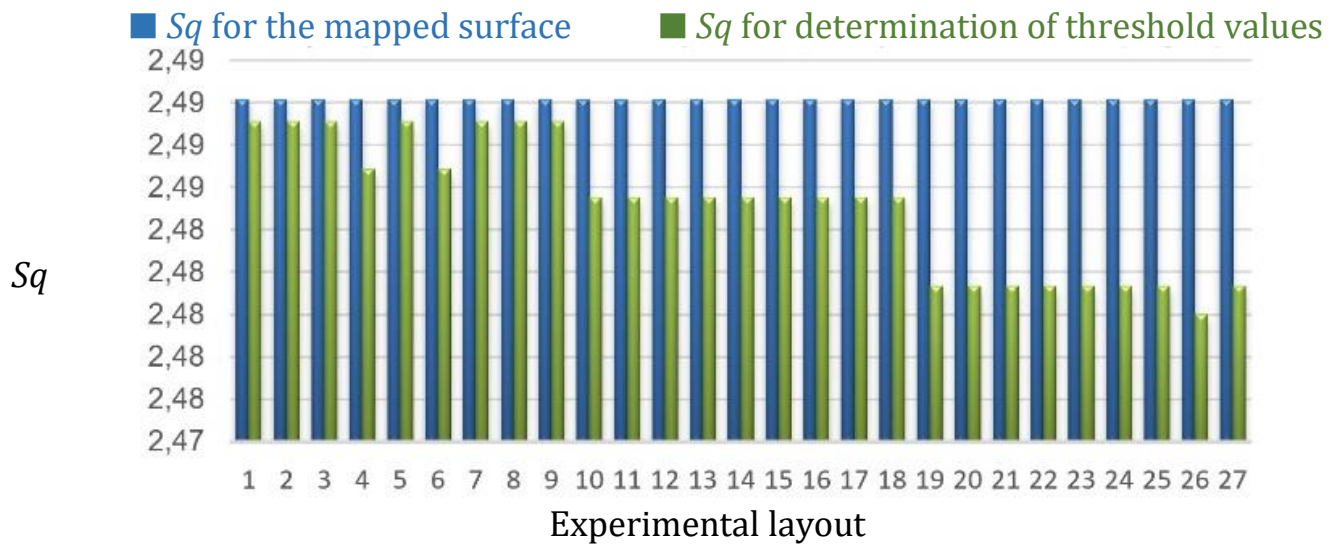

Fig. 1. Summary of the value of the $S q$ parameter of the mapped surface and the determined threshold value for 27 experiment systems

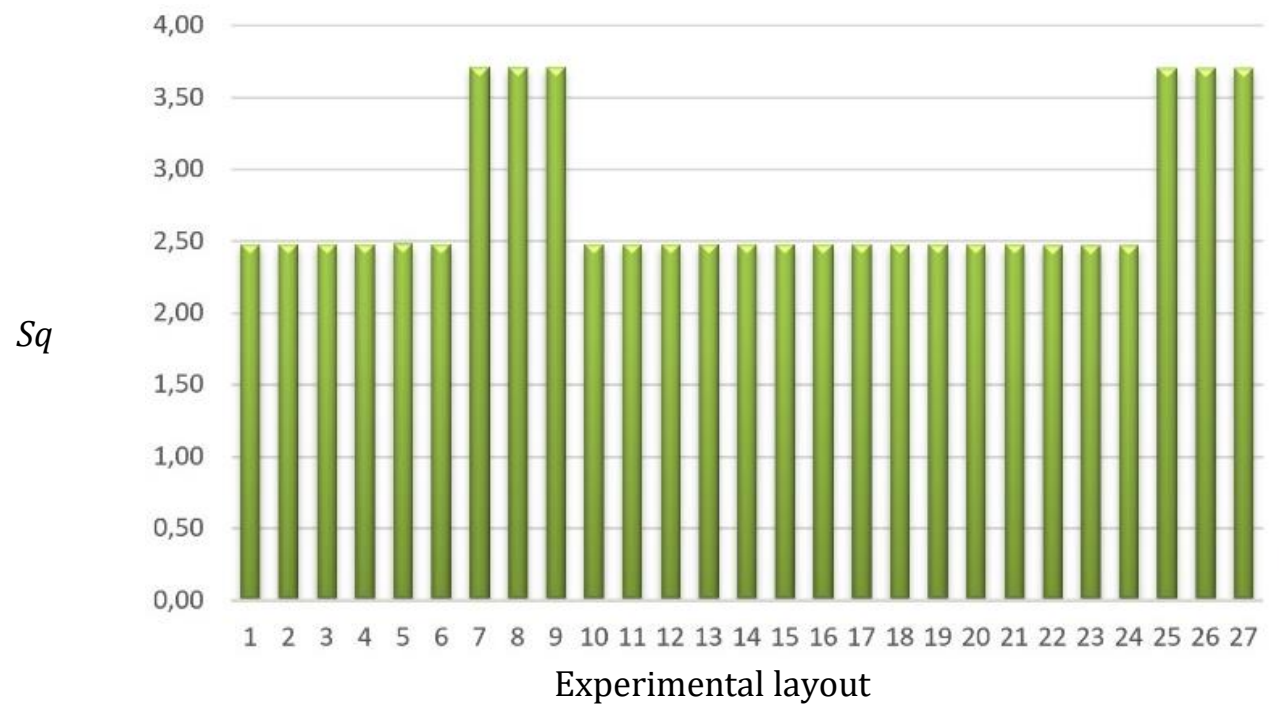

Fig. 2. Summary of the $S q$ parameter value for the level surface for 27 experiment systems 


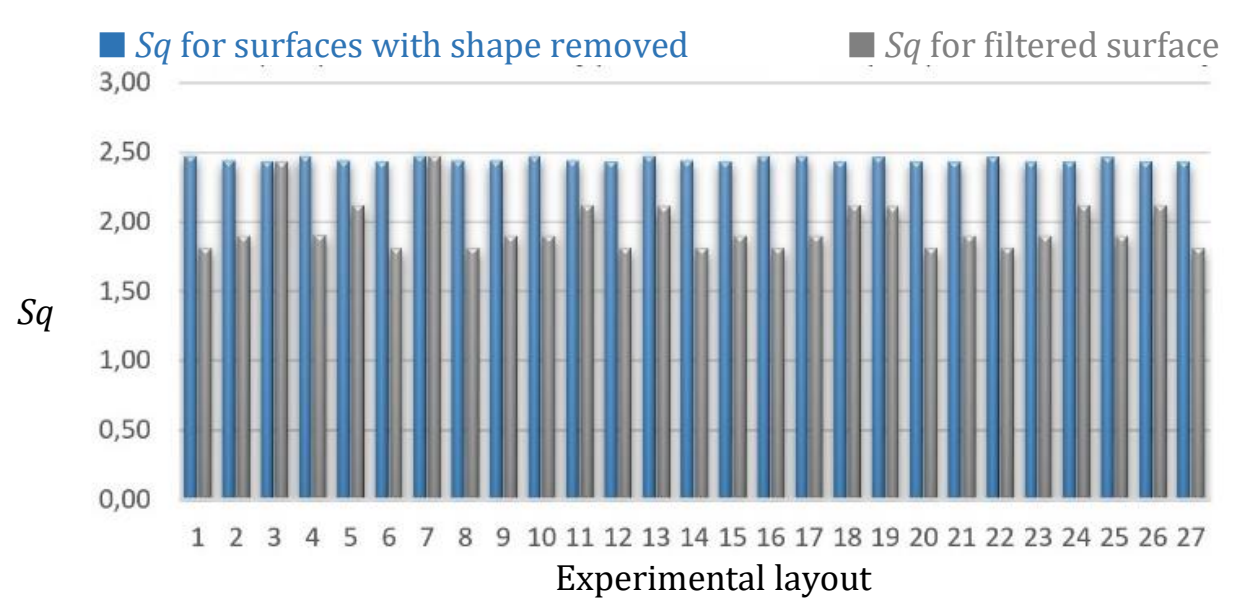

Fig. 3. Summary of the $S q$ parameter value of the surface with the shape removed and filtered for 27 experiment systems
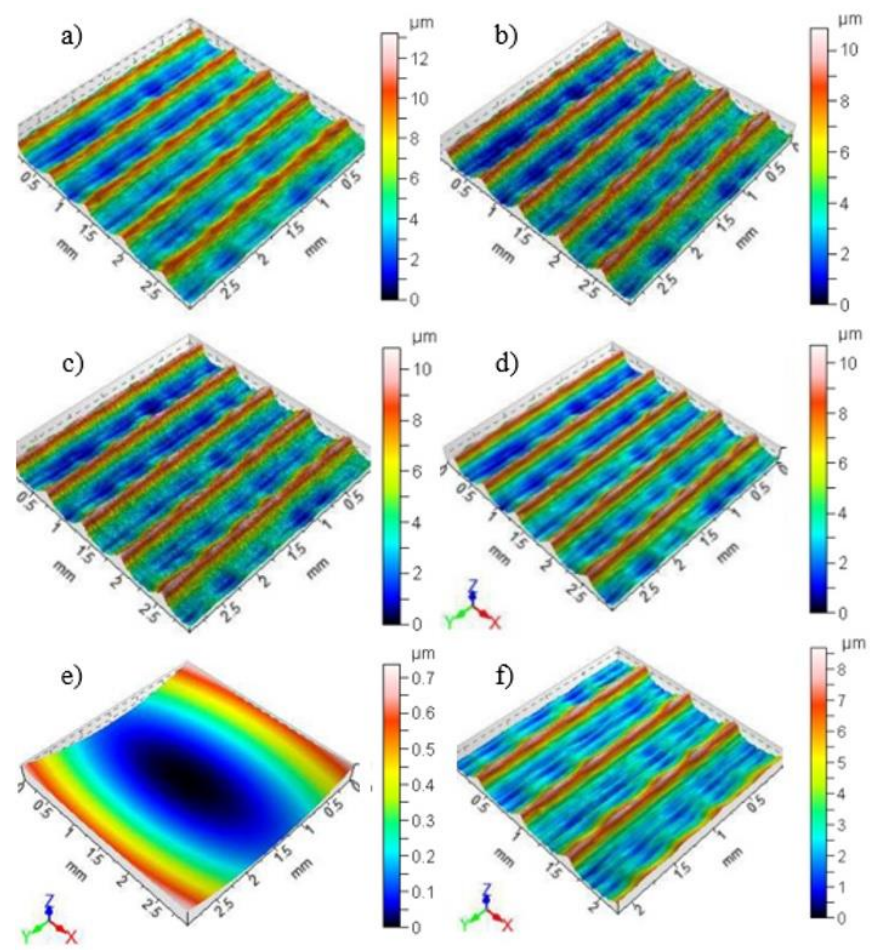

Fig. 4. List of isometric images of milled samples: a) reproduced surface; b) cutting out threshold values; $c$ ) leveled surface; d), e) removing the shape; f) surface filtration

After removing the shape and filtering, the values of $S q$ parameter decreased by $20 \%$ on average. In two cases, for systems 3 and 8, the parameter values did not change. Fig. 4 shows system 1, visualizing the various stages of surface filtration.

Reduced values of the $S q$ parameter, determined by filtration from the mapped value, are smaller by approximately $22 \%$, which is an important observation that affects the interpretation of measurement results.

\section{Summary}

The PN-EN ISO 25178-2: 2012 standards precisely define the relationships used to determine the values of individual SGP parameters, however, they do not clearly specify how to carry out the process of point cloud acquisition and what should be the methodology for processing measurement data by digital processing.

During the analysis, some trends were observed for the mean square surface deviation Sq. Considering the order of the data processing steps carried out, it can be seen that for 27 experimental systems the mapped surface was characterized by the largest parameter indications. 
Significant impact of the digital processing of measurement data has been confirmed, resulting in a change in the $S q$ value - even by approximately $20 \%$ relative to the mapped value. Also, filtration has significant impact on reducing the value of $S q$ parameter by about $27 \%$.

The consequence of the cause-effect relationships indicated in the paper is an ambiguous interpretation of the real quality of the processed surface. Based on the same measurement data, different conclusions can be drawn about the state of the surface depending on the method used for digital processing.

Based on the determined coefficient of variation, it was found out by how much the $S q$ parameter is reduced as a result of using the selected method of measuring signal processing.

It was confirmed that changes in the $S q$ parameter are the result of choosing a specific method of digital measurement data processing, and a problem was found related to the significant impact of the operator (metrologist) on the final results of the measurement procedure. The lack of harmonized standards regarding the point cloud acquisition procedure and the method of digital processing of measurement data gives the metrologist the opportunity to reduce the $S q$ parameter to the value given in the technological specification, which creates problems with achieving reproducibility of measurement results and should not occur in industrial practice. It is possible that the lack of repeatability of the measurement procedure will lead to complaints about production batches, which in fact comply with the customer's specification.

\section{REFERENCES}

[1] Miller T., Adamczak S., Świderski J., Wieczorowski M., Łętocha A., Gapiński B. "Influence of temperature gradient on surface texture measurements with the use of profilometry". Bulletin of the Polish Academy of Sciences -Technical Sciences. 65 (2017).

[2] Wieczorowski M., Gapiński B., Grochalski K., Miller T. „Teoretyczne aspekty analizy wybranych źródeł błędów w profilowych pomiarach nierówności powierzchni". Mechanik. 4 (2017): 335-338, https://doi.org/10.17814/mechanik.2017.4.53.

[3] Miller T. „Źródła niewiarygodności pomiarów topografii powierzchni”. Mechanik. 11 (2016), http://dx.doi.org/10.17814/mechanik.2016.11.509.

[4] PN-EN ISO 25178-603:2013-12 Specyfikacje geometrii wyrobów (GPS). Struktura geometryczna powierzchni: Przestrzenna - Część 603. Charakterystyki nominalne przyrządów bezstykowych (mikroskopów interferometrycznych z korekcją fazy).

[5] PN-EN ISO 25178-602:2010. Specyfikacje geometrii wyrobów. Struktura geometryczna powierzchni: Przestrzenna - Część 602. Charakterystyki nominalne przyrządów bezstykowych (z czujnikiem chromatycznym konfokalnym).

[6] Pawlus P., Wieczorowski M., Mathia T. „The errors of stylus methods in surface topography measurements". Szczecin: ZAPOL Szczecin, Sobczyk Sp.J., 2014.

[7] PN-EN ISO 25178-2:2012. Specyfikacje geometrii wyrobów (GPS). Struktura geometryczna powierzchni: Przestrzenna - Część 2. Terminy, definicje i parametry struktury geometrycznej powierzchni.

[8] PN-EN ISO ISO 25178-1:2016 (en). Geometrical product specifications (GPS). Surface texture: Areal Part 1. Indication of surface texture.

[9] Bachtiak-Radka E., Dudzińska S., Grochała D., Berczyński S. "Susceptibility of SPG parameters to the environment conditions and the method of acquisition of cloud of points with optical measuring systems applied". Mechanik. 8-9 (2017), https://doi.org/10.17814/mechanik.2017.8-9.108.

[10] Leach R.K., Giusca C.L., Haitjema H., Evans C., Jiang X. "Calibration and verification of areal surface texture measuring instruments". CIRP Annals - Manufacturing Technology. 64 (2015).

[11] Leach R. "The measurement of surface texture using stylus instruments". Measurement Good Practice Guide. 37 (2014).

[12] Whitehouse D.J. "A revised philosophy of surface measuring systems". Proceedings of the Institution of Mechanical Engineers. Part C: Journal of Mechanical Engineering Science. 202 (1988).

[13] Neubert N.K.P. "Instrument Transducers: An Introduction to Their Performance and Design". Oxford: Oxford University Press, 1963.

[14] Dudzińska S., Szydłowski M., Grochała D., Bachtiak-Radka E. "Application of correlation function for analysis of surface structure shaping by hybrid manufacturing technology". Advances in Manufacturing. 1 (2018).

[15] Grochała D., Berczyński S., Grządziel Z. "Modeling of burnishing thermally toughened X42CrMo4 steel with a ceramic $\mathrm{ZrO}_{2}$ ball". Archives of Civil and Mechanical Engineering. 9 (2017). 